Collection: Cost Action E29 Meeting 2008 - Istanbul (Turkey)

Future Monitoring and Research Needs for Forest Ecosystems

Guest Editor: Marcus Schaub (WSL, Birmensdorf, CH)

\title{
Modelling the carbon budget of intensive forest monitoring sites in Germany using the simulation model BIOME-BGC
}

\author{
Jochheim $H^{(1)}$, Puhlmann $M^{(1)}$, Beese $F^{(2)}$, Berthold $D^{(2)}$, Einert $\mathbf{P}^{(3)}$, \\ Kallweit $\mathbf{R}^{(3)}$, Konopatzky A ${ }^{(3)}$, Meesenburg $\mathrm{H}^{(4)}$, Meiwes K-J ${ }^{(4)}$, \\ Raspe $S^{(5)}$, Schulte-Bisping $H^{(2)}$, Schulz $C^{(5)}$
}

It is shown that by calibrating the simulation model BIOME-BGC with mandatory and optional Level II data, within the ICP Forest programme, a well-founded calculation of the carbon budget of forest stands is achievable and, based on succeeded calibration, the modified BIOME-BGC model is a useful tool to assess the effect of climate change on forest ecosystems.

Keywords: Monitoring, Carbon budget, Modelling, Climate change

\section{Introduction}

The main focus of the intensive monitoring of forests (Level II) within the ICP Forest programme of the UN-ECE is the investigation of effects of atmospheric deposition on element budgets, soil chemistry, crown condition, and tree growth of forest ecosystems. Investigations on forest carbon budget are limited to the sampling of stem increments within a 5 years interval. In a limited number of stands some supplementary measurements

(1) Leibniz-Centre for Agricultural Landscape Research, Eberswalder Str. 84, D15374 Müncheberg, Germany; (2) Institute of Soil Science and Forest Nutrition, University Göttingen, Büsgenweg 2, D-37077 Göttingen, Germany; (3) Landesforstanstalt Eberswalde, Alfred-Möller-Str. 1, D-16225 Eberswalde, Germany; (4) Nordwestdeutsche Forstliche Versuchsanstalt, Grätzelstr. 2, D-37079 Göttingen, Germany; (5) Bayerische Landesanstalt für Wald und Forstwirtschaft, Am Hochanger 11, D-85354 Freising, Germany

@) Hubert Jochheim (hjochheim@zalf.de)

Received: Mar 27, 2008 - Accepted: Dec 09, 2008

Citation: Jochheim $\mathrm{H}$, Puhlmann M, Beese $\mathrm{F}$, Berthold D, Einert $P$, Kallweit R, Konopatzky A, Meesenburg H, Meiwes K-J, Raspe S, Schulte-Bisping H, Schulz C, 2009. Modelling the carbon budget of intensive forest monitoring sites in Germany using the simulation model BIOME-BGC. iForest 2: 7-10 [online: 2009-01-21] URL:

http://www.sisef.it/iforest/show.php? id $=475$ are carried out concerning the above and below ground carbon turnover.

The aim of this study was the assessment of additional measurements (litter fall, permanent girth measurement, tree ring analyses, soil respiration, long term development of soil carbon, soil physics, soil moisture) to improve the initialization, calibration and validation of dynamic simulation models with respect to the carbon budget of forest ecosystems. The validated simulation models can be applied for the assessment of the impact of climate change on the carbon budget of forests.

\section{Methods}

Sixteen German Level II plots with Fagus

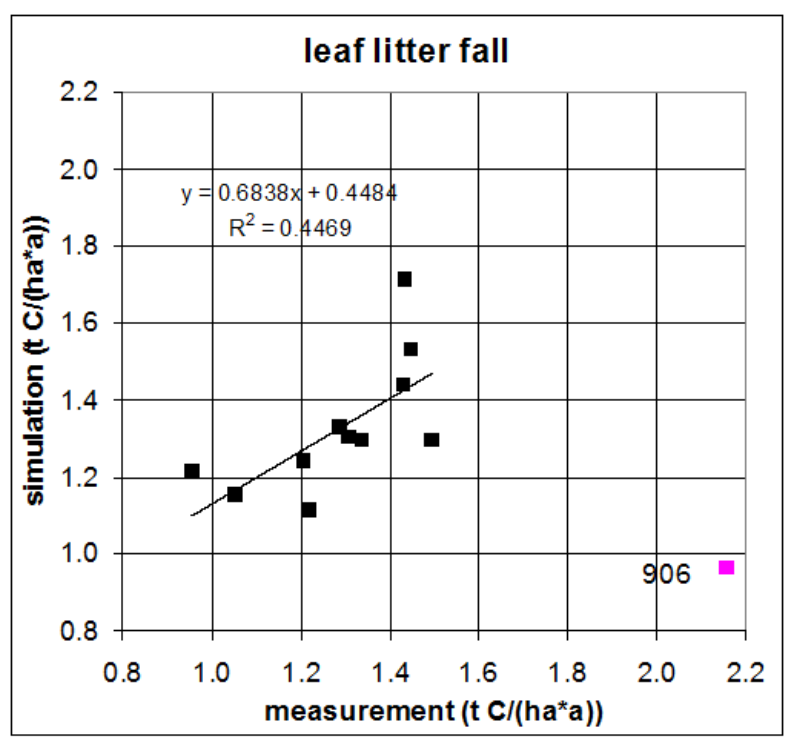

sylvatica (3), Pinus sylvestris (8) and Picea abies (5) were selected, where the measurements of the mandatory and optional programmes (meteorology, stand precipitation, soil moisture, deposition, soil solution, soil chemistry, stem biomass (5 years cycle), stem girth measurements, litter fall, crown condition, foliar analysis) and in some cases data on soil physics, tree ring analyses, and sap flow were available. At these plots soil respiration was measured, additionally (Badeck et al. 2007). For differentiation between heterotrophic and root respiration the trenching technique was used (Hanson et al. 2000).

In our investigation the data were used for the initialization and calibration of BIOMEBGC version 4.2 (Thornton et al. 2002 http://www.ntsg.umt.edu/models/bgc/), a simulation model for calculating the energy, water, carbon, and nitrogen budget of biomes. For the purpose of the project the programme code of BIOME-BGC was extended by a forest management module, a multilayered soil water, $\mathrm{C}$, and temperature module, and a root growth module. The programme code concerning phenology, decomposition, canopy evaporation and transpiration modules was modified. At the present status the model shows a more species and stand specific behavior. The number of ecophysiological model parameters (including management) was enhanced from 37 to 80 .

The carbon and water budgets of these 16 Level-II sites were calculated for the simulation period 1996-2005 using meteorological data of the open field measurements of the plots.

For analyzing the effects of climate change, the climate scenarios of the statistical model STAR (Orlowsky 2007) for the DWD stations and the years 2046-2055, based on the SRES emission scenario A2 of the IPCC and the global climate model

Fig. 1 - Simulation results compared to measurements: litter fall. 
Fig. 2 - Simulation results compared to measurements: wood increment. wood increment (coarse + fine wood)

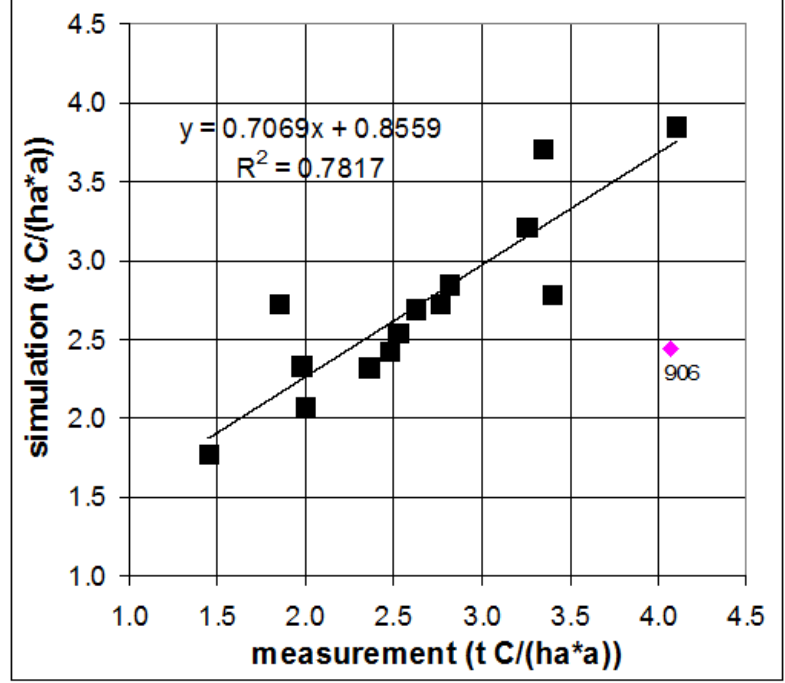

ECHAM5-MPI-OM were used. For the base and climate change scenarios identical initial model values were used. The climate change scenarios consider the predicted atmospheric $\mathrm{CO}_{2}$ concentrations, too, but did not use changing nitrogen deposition.

\section{Results}

Comparisons of simulation results with measurements on stand precipitation, soil moisture, and sap flow demonstrate, that the model BIOME-BGC (including modifications) allows a precise simulation of water budget (not depicted). The same applies to soil temperature.

The long term averages of leaf litter fall and stem growth can be simulated with satisfying precision, if the plot number 906 is disregarded (Fig. 1, Fig. 2). In some stands basal area increment from tree ring analyses are weakly correlated to simulated stem incre-
Fig. 3 - Simulation results compared to measurements: deviation of the measured

basal area increment from hyperbolic

trend compared to the deviation of the simulated current annual stem increment from the linear trend.

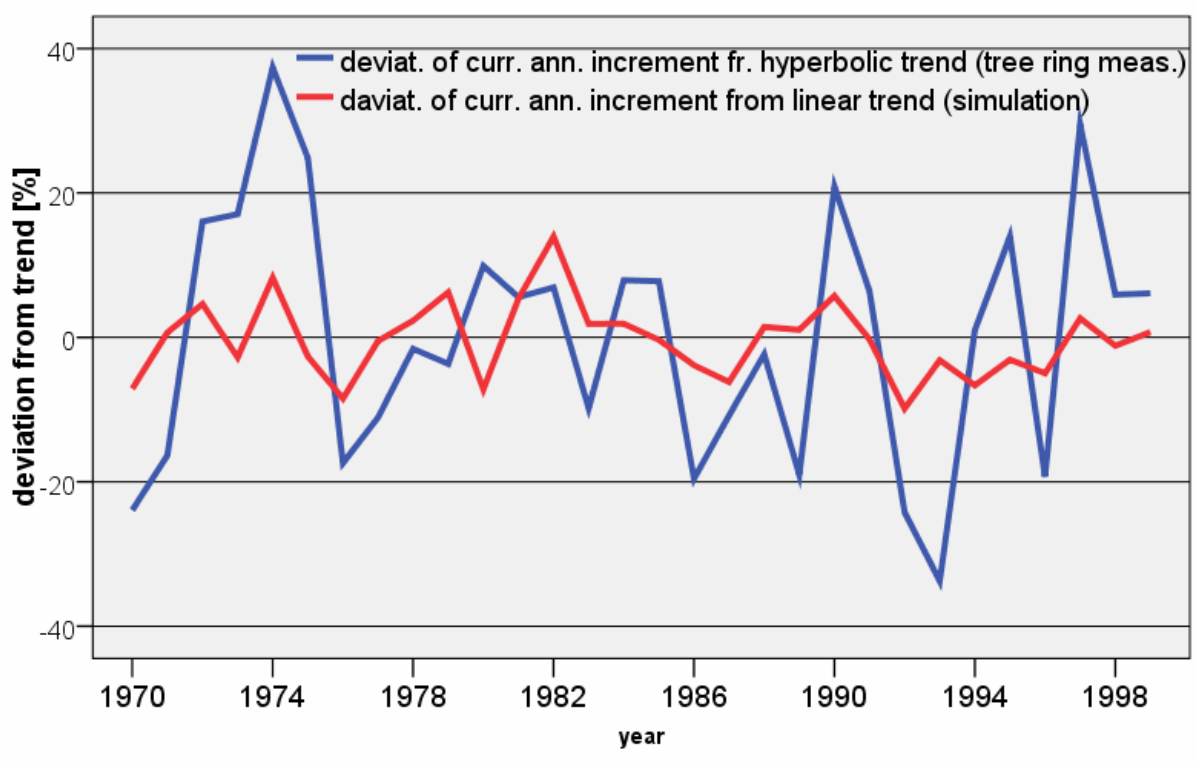

Fig. 4 - Simulation results compared to measurements: soil respiration (heterotrophic + root respiration).

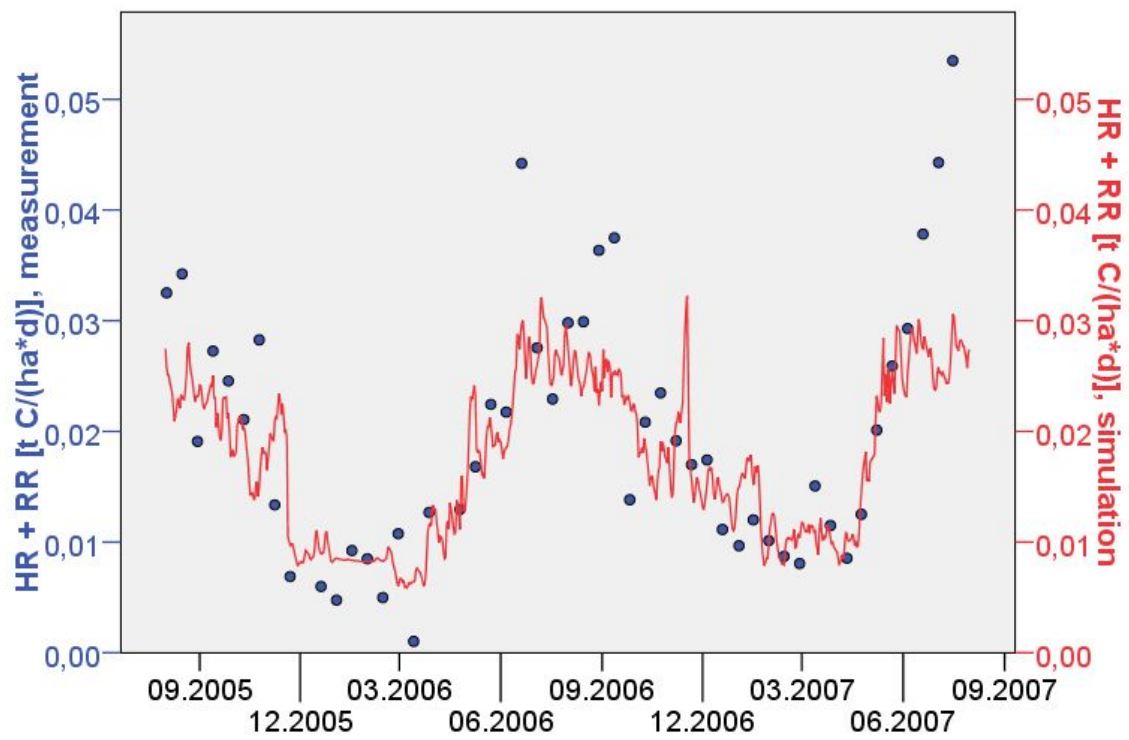




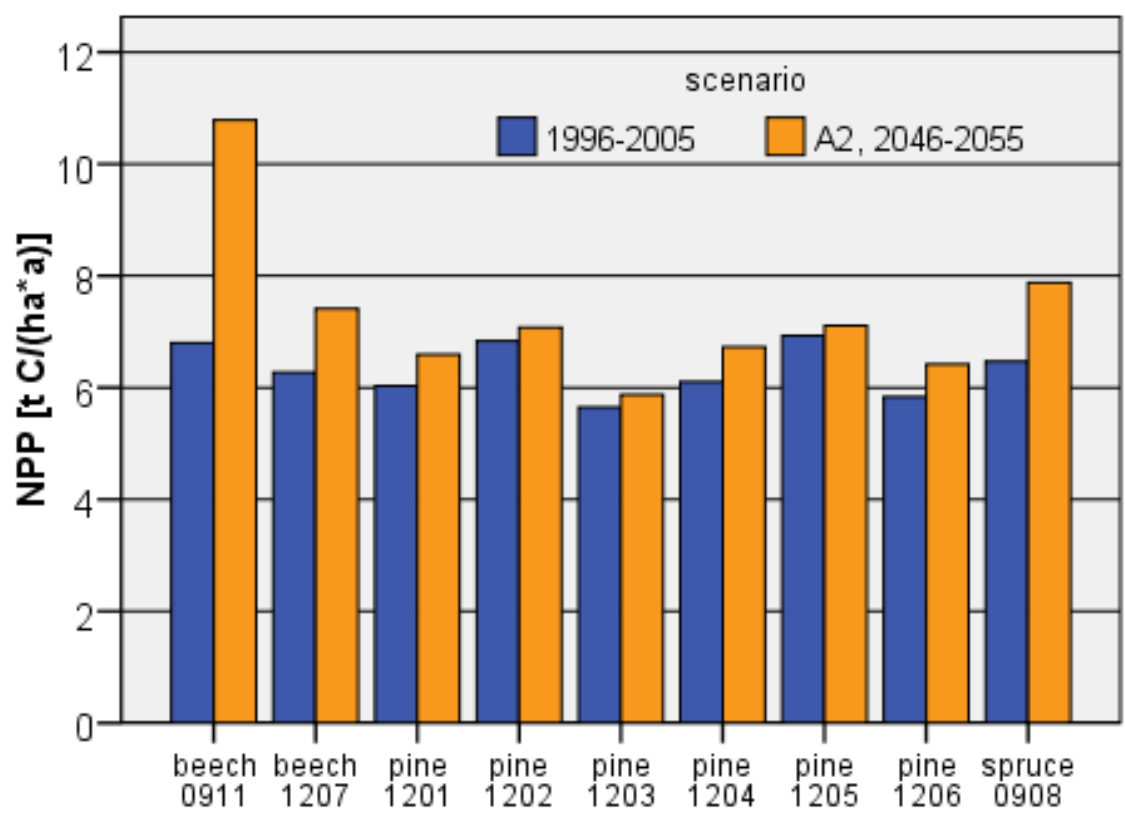

Fig. 5 - Simulated net primary production (NPP) under climate change scenarios compared to the measured climate data.

ment, mainly in pine stands on sandy soils of Brandenburg (Fig. 3). The annual variation of measured values of leaf litter fall and stem growth exceeds the annual variation of simulation results.

Repeated measurements of soil carbon are only available for two stands (Solling beech and spruce). In these stands, the increasing soil carbon stocks cannot be found in the current simulation results. Instead, a slow decrease is simulated (not depicted).

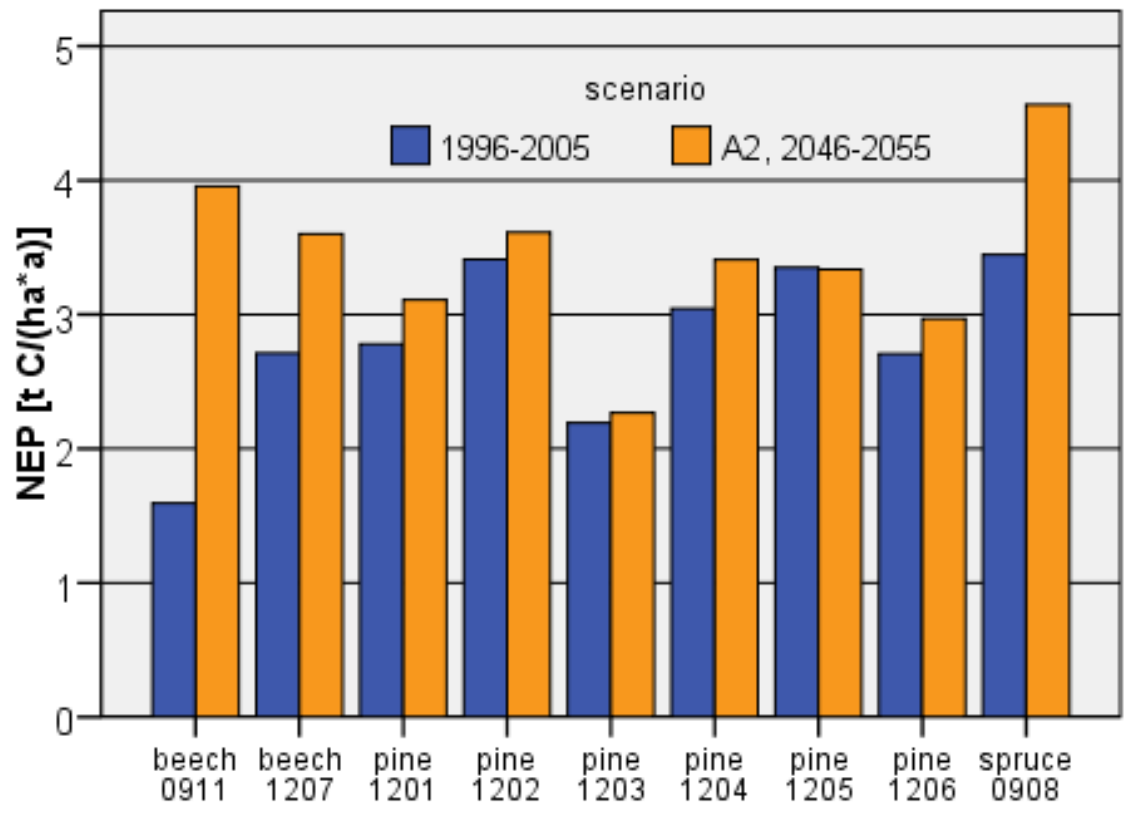

Fig. 6 - Simulated net ecosystem production (NEP) under climate change scenarios compared to the measured climate data. other hand, the plant and heterotrophic respiration is rising, too. The carbon sequestration of the stands (NEP) is increased under the climate change scenarios (Fig. 6). Due to reduced precipitation, a weak reduction of evaporation and a considerable reduction of soil water outflow ( $43 \%$ of base scenario) are predicted (not depicted). Transpiration reacts different depending on tree species and site conditions.

\section{Discussion}

Correct simulations of hydrology and the soil temperature of the forest ecosystem, as realized in this investigation, are essential preconditions for estimating the carbon budget of forest ecosystems with dynamic simulation models.

Even if simulated leaf litter fall and stem growth more or less agree with measurements, the higher annual variations of observations compared to those of simulations indicates, that the model does not yet consider all essential factors determining stem and leaf growth (e.g., fructification, air pollutants). In case of the plot number 906 successful model calibration is not possible. This is may caused by data errors on driving forces, initial values, or on data for calibration.

trophic + root resp.) can be reproduced by the model predictions, with the exception of some peaks in summer (Fig. 4). Major deviations occur if measurements at soil sites with trenched roots are interpreted as heterotrophic respiration and compared to simulation results (not depicted).

Simulations using climate change scenarios showed an increasing productivity (GPP, NPP, stem and leaf growth - Fig. 5). On the

The divergent simulation results on development of soil carbon pools compared to measurements may have different causes. First, the spatial heterogeneity of soil carbon leads to a wide range of data (Lloyd \& McKee 1983, Klinck et al. 2008) that complicate model initialization and calibration. Additionally, measurements on coarse woody debris are lacking, and data on root turnover, one of the main input-path of organic matter into the soil, are uncertain. Finally, seed production as a further pathway of organic matter into the litter layer is neglected by the model.

With respect to these uncertainties the additional soil respiration measurements represent valuable data for model initialization and calibration. Measured soil respiration with living roots could be simulated satisfactorily. In contrast, the root trenching technique for separation of root and heterotrophic respiration may produce some artifacts, at least under dry summer conditions. Thus, the latter measurements are an uncertain database for model calibration aiming on separated consideration of root and heterotrophic respiration.

The climate change scenarios applied in this investigation are characterized by rising temperature and atmospheric $\mathrm{CO}_{2}$ concentrations and decreasing precipitation. The application of these climate change scenarios are connected to some artifacts caused by systematic climate differences between the meteorological stations of the national weather service (used for climate change 
scenarios) and open land stations belonged to Level II plots (used for base scenarios).

The simulation results on climate change effects on water budget with decreasing evaporation and water outflow are in line with other investigations (Gerstengarbe et al. 2003). The results of higher wood production under climate change conditions are in agreement with analyses on growth trends of the past (Spiecker 1999, Boisvenue \& Running 2006) and simulation studies for future development (Lasch et al. 2002, Eggers et al. 2008). Obviously, the simulated rising water stress at some Level II plots is counteracted by the fertilizing effect of rising $\mathrm{CO}_{2}$ concentration. By contrast, a simulation study on pine stands in Brandenburg (Germany) reports reduced productivity (Lasch \& Suckow 2007). In Europe different gradients (northsouth, altitude, maritime-continental) of forest growth reaction on climate change are expected. In the boreal zone the limiting low temperature effect will be reduced, whereas in the Mediterranean zone the limiting drought effect is expected to be enhanced (Kellomäki et al. 2005, De Vries et al. 2007).

\section{Conclusions}

The monitoring data from the current mandatory and optional Level II programme provide valuable information for calibration of dynamic simulation models for calculating the carbon budget of forest ecosystems. Additionally, the data offer some hints for further model development. By calibrating the simulation model BIOME-BGC with mandatory and optional Level II data, a wellfounded calculation of the carbon budget of forest stands is achievable. Furthermore, based on succeeded calibration, the modified BIOME-BGC model is a useful tool to assess climate change effects on forest ecosystems.

\section{Acknowledgements}

These results are part of a project that was financially supported by the European Commission, Contract No. Forest Focus - DE
2003/2004 BB 5, DE 2003/2004 BY 4, DE 2003/2004 NI 6 .

\section{References}

Badeck FW, Beese F, Berthold D, Einert P, Jochheim H, Kallweit R, Konopatzky A, Lasch P, Meesenburg H, Meiwes KJ, Puhlmann M, Raspe S, Schulte-Bisping H, Schulz C, Suckow F (2007). Parametrisierung, Kalibrierung und Validierung von Modellen des Kohlenstoffumsatzes in Waldökosystemen und deren Böden. Abschlussbericht Forest Focus C2-Projekte DE 2003/2004 BB 5, DE 2003/2004 BY 4, DE 2003/2004 NI 6, pp. 110.

Boisvenue C, Running SW (2006). Impacts of climate change on natural forest productivity - evidence since the middle of the $20^{\text {th }}$ century. Global Change Biology 12: 862-882 - doi: 10.1111/j.1365-2486.2006.01134.x

De Vries W, Wamelink GWW, Reinds GJ, Wieggers HJJ, Mol-Dijkstra JP, Kros H, Nabuurs GJ, Pus-sinen A, Solberg B, Dobbertin M, Laubhann D, Sterba H, Van Oijen M (2007). Assessment of the relative importance of nitrogen deposition, climate change and forest management on the sequestration of carbon by forests in Europe. Alterra Rapport 1538: pp. 302.

Eggers J, Lindner M, Zudin S, Zaehle S, Liski J (2008). Impact of changing wood demand, climate and land use on European forest resources and carbon stocks during the $21^{\text {st }}$ century. Global Change Biology 14: 2288-2303. - doi: 10.1111/j.1365-2486.2008.01653.x

Gerstengarbe FW, Badeck F, Hattermann F, Krysanova V, Lahmer W, Lasch P, Stock M, Suckow F, Wechsung F, Werner PC (2003). Studie zur klimatischen Entwicklung im Land Brandenburg bis 2055 und deren Auswirkungen auf den Wasserhaushalt, die Forst- und Landwirtschaft sowie die Ableitung erster Perspektiven. PIK Report 83: pp. 77.

Hanson PJ, Edwards NT, Garten CT, Andrews JA (2000). Separating root and soil microbial contributions to soil respiration: A review of methods and observations. Biogeochemistry 48: 115-146. - doi: 10.1023/A:1006244819642

Kellomäki S, Peltola H, Bauwens B, Dekker M, Mohren F, Badeck F-W, Gracia C, Sánchez A,
Pla E, Sabaté S (2005). European mitigation and adaptation potentials: conclusions and recommendation. In: "Management of European forests under changing climatic conditions" (Kellomäki S, Leinonen S eds). Final Report of the Project: "Silvicultural response strategies to climatic change in management of european forests", pp. 402-427.

Klinck U, Fröhlich D, Meiwes KJ (2008). Zur Problematik der Quantifizierung von C- und NGehalten, C/N-Verhältnissen und $\mathrm{C}$ - und N-Vorräten der Humusauflage und des mineral-ischen Oberbodens. Allgemeine Forst und Jagdzeitung 179: 1-7.

Lasch P, Suckow F (2007). Reaktion von Kiefernbeständen unter Klimaänderungen - eine Analyse mit dem Waldwachstumsmodell 4C. In: "Kiefer im nordostdeutschen Tiefland - Ökologie und Bewirtschaftung” (Kätzel R, Möller K, Löffler S, Engel J, Liero K eds). Eberswalder Forstliche Schriftenreihe 32: 230-237.

Lasch P, Badeck F-W, Lindner M, Suckow F (2002). Sensitivity of simulated forest growth to changes in climate and atmospheric $\mathrm{CO}_{2}$. Forstwissenschaftliches Centralblatt 121 (Suppl. 1): $155-171$

Lloyd FT, McKee WH (1983). Replications and subsamples needed to show treatment responses on forest soils of the coastal plain. Soil Science Society of America Journal 47: 587-590.

Orlowsky B (2007). Setzkasten Vergangenheit ein kombinatorischer Ansatz für regionale Klimasimulationen. $\mathrm{PhD}$ thesis, Department of Geoscience, University Hamburg, Germany, pp. 187.

Spiecker H (1999). Overview of recent growth trends in European forests. Water Air and Soil Pollution 116: 33-46. - doi: 10.1023/A: 1005205515952

Thornton PE, Law BE, Gholz HL, Clark KL, Falge E, Ellsworth DS, Golstein AH, Monson RK, Hollinger D, Falk M, Chen J, Sparks JP (2002). Modeling and measuring the effects of disturbance history and climate on carbon and water budgets in evergreen needleleaf forests. Agricultural and Forest Meteorology 113: 185222. - doi: 10.1016/S0168-1923(02)00108-9 